Proc. Estonian Acad. Sci. Geol., 1998, 47, 4, 229-241

\title{
AUTHIGENIC OVERGROWTHS OF DETRITAL FELDSPAR GRAINS IN THE DEVONIAN SEQUENCE OF THE EAST BALTIC
}

\author{
Anne KLEESMENT
}

Institute of Geology at Tallinn Technical University, Estonia pst. 7, 10143 Tallinn, Estonia; e-mail: kleesmen@gi.ee

Received 20 October 1997, in revised form 1 December 1997

Abstract. The formation of authigenic feldspar overgrowths was examined by the immersion method in 784 samples of Devonian sediments collected from 39 drill cores and 27 outcrops of 6 localities in the East Baltic. The studied sequence is up to $1000 \mathrm{~m}$ thick and it contains loose and dolomite-cemented, often thinly laminated sand- and siltstones, domerites, dolomites, and clays.

The presence of angular transparent overgrowths in levels with strongly rounded mineral grains, distinct lithological control, and certain paragenesis with other diagenetic alterations suggest that the authigenic feldspar overgrowths formed in the sections under consideration during the postdepositional period. Abundant overgrowths appeared during the middle phases of diagenesis in loose sandstones, thinly intercalating with red-coloured clays or domerites. The process was most intensive in restricted collectors between clays or dolomitic interlayers, where saturated interlayer solutions developed. The presence of iron (hydr)oxides favoured the formation of feldspar overgrowths, whereas kaolinite precipitation inhibited this process. According to the obtained data, the formation of feldspar overgrowths did not depend on the burial depth of the deposits. The low content of authigenic feldspar in sediments suggests that potassium originated from the dissolution of detrital feldspar grains within the rocks.

Key words: feldspar, authigenic overgrowths, diagenesis, Devonian, Baltic.

\section{INTRODUCTION}

The knowledge about authigenic overgrowths of detrital feldspar grains goes back for over a hundred years. Since Rosen first described them in dolomites in 1864 (cited in Pustovalov, 1956), these rims have been examined in all kinds of sedimentary rocks. However, the time and conditions of the formation of overgrowths are still debated. According to some authors, overgrowths formed 
during sedimentation and early diagenesis (Pettijohn, 1957); they have been considered as products of later (Baskin, 1956; Khodak,-1956; Rukhin, 1956; Strakhov, 1957; Kopeliovich, 1965) or latest diagenetic alteration (Kossovskaya \& Shutov, 1956). In more recent studies early diagenetic origin is mostly regarded as prevailing (Rajulu \& Nagaraja, 1967; Viswanathiah \& Rao, 1968; Dapples, 1979; Pollastro, 1989; Faure, 1992; Diehl \& Goldhaber, 1995).

Also, the provenance of the precipitating material forming overgrowths is disputable. It has been suggested that small amounts of overgrowths may have been furnished by dissolution-precipitation of detrital feldspar grains within a single rock bed; however, for the formation of a large amount of authigenic feldspar it was necessary that some potassium was imported into the rock (Hansley, 1995).

Supposedly, the formation of overgrowths required the presence of considerable amounts of silica (Viczian, 1992), in some cases also iron (Diehl \& Goldhaber, 1995).

\section{GEOLOGICAL SETTING}

Overgrowths of feldspars were explored in sedimentary rocks of the Devonian sequence of the East Baltic (Fig. 1), comprising the Lower and Middle series

(Table 1). The lowermost part of the sequence consists of intercalating loose

Table 1

Stratigraphy of the explored part of the East Baltic Devonian sequence

\begin{tabular}{|c|c|c|c|c|c|}
\hline Series & Stage & $\begin{array}{l}\text { Regional } \\
\text { stage }\end{array}$ & $\begin{array}{l}\text { Regional } \\
\text { substage }\end{array}$ & $\begin{array}{c}\text { Maximum } \\
\text { thickness, } \mathrm{m}\end{array}$ & Dominating rock types \\
\hline \multirow{6}{*}{$\begin{array}{l}\text { Middle } \\
\text { Devonian }\end{array}$} & Givetian & Burtnieki & & 100 & Sandstone \\
\hline & \multirow{5}{*}{ Eifelian } & Aruküla & & 100 & Silty sandstone \\
\hline & & \multirow{3}{*}{ Narva } & Kernavė & 35 & $\begin{array}{l}\text { Sand-and siltstone, intercalating } \\
\text { with domerite and clay }\end{array}$ \\
\hline & & & Leivu & 60 & $\begin{array}{l}\text { Intercalation of domerite, dolomite, } \\
\text { siltstone, and clay }\end{array}$ \\
\hline & & & Vadja & 20 & $\begin{array}{l}\text { Intercalation of domerite, } \\
\text { dolomites, and clay }\end{array}$ \\
\hline & & Pärnu & & 30 & Sandstone \\
\hline \multirow{3}{*}{$\begin{array}{l}\text { Lower } \\
\text { Devonian }\end{array}$} & Emsian & Rēzekne & & 50 & Sandstone \\
\hline & Pragian & Ķemeri & & 100 & Sandstone \\
\hline & Lochkovian & $\begin{array}{l}\text { Stoniškiai, } \\
\text { Tilze }\end{array}$ & & 200 & $\begin{array}{l}\text { Intercalation of sandstone, } \\
\text { siltstone, and clay }\end{array}$ \\
\hline
\end{tabular}




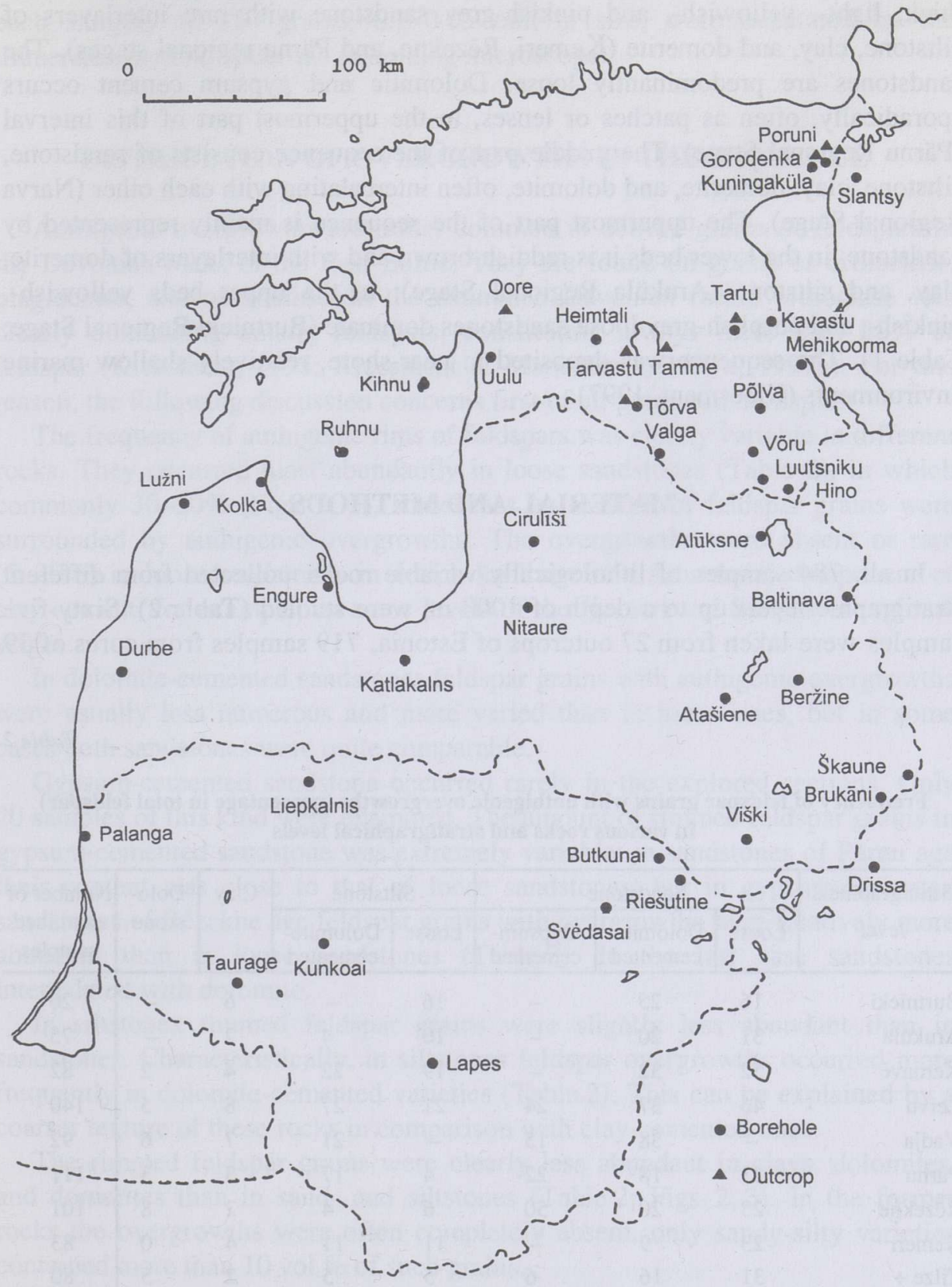

Fig. 1. Location of the examined sections. 
sandstone, siltstone, and clay (Tilze and Stoniškiai regional stages), overlain by thick, light-, yellowish-, and pinkish-grey sandstone with rare interlayers of siltstone, clay, and domerite (Kemeri, Rēzekne, and Pärnu regional stages). The sandstones are predominantly loose. Dolomitic and gypsum cement occurs sporadically, often as patches or lenses, in the uppermost part of this interval (Pärnu Regional Stage). The middle part of the sequence consists of sandstone, siltstone, clay, domerite, and dolomite, often intercalating with each other (Narva Regional Stage). The uppermost part of the sequence is mainly represented by sandstone: in the lower beds it is reddish-brown and with interlayers of domerite, clay, and siltstone (Aruküla Regional Stage); in the upper beds yellowish-, pinkish-, and purplish-grey loose sandstones dominate (Burtnieki Regional Stage; Table 1). The sequence was deposited in near-shore, relatively shallow marine environments (Kleesment, 1997).

\section{MATERIAL AND METHODS}

In all, 784 samples of lithologically variable rocks, collected from different stratigraphic levels up to a depth of $1000 \mathrm{~m}$, were studied (Table 2). Sixty-five samples were taken from 27 outcrops of Estonia, 719 samples from cores of 39

Table 2

Frequency of feldspar grains with authigenic overgrowths (percentage in total feldspar) in various rocks and stratigraphical levels

\begin{tabular}{|c|c|c|c|c|c|c|c|c|}
\hline \multirow{2}{*}{$\begin{array}{c}\text { Stratigraphical } \\
\text { level }\end{array}$} & \multicolumn{3}{|c|}{ Sandstone } & \multicolumn{2}{|c|}{ Siltstone } & \multirow[t]{2}{*}{ Clay } & \multirow{2}{*}{$\begin{array}{l}\text { Dolo- } \\
\text { stone }\end{array}$} & \multirow{2}{*}{$\begin{array}{c}\text { Number of } \\
\text { examined } \\
\text { samples }\end{array}$} \\
\hline & Loose & $\begin{array}{l}\text { Dolomite- } \\
\text { cemented }\end{array}$ & $\begin{array}{l}\text { Gypsum- } \\
\text { cemented }\end{array}$ & Loose & $\begin{array}{l}\text { Dolomite- } \\
\text { cemented }\end{array}$ & & & \\
\hline Burtnieki & 16 & 25 & - & 16 & - & 6 & - & 20 \\
\hline Aruküla & 31 & 20 & - & 10 & 4 & 2 & - & 75 \\
\hline Kernavè & 52 & 32 & - & 19 & 22 & 4 & 2 & 82 \\
\hline Leivu & 46 & 37 & 24 & 21 & 27 & 8 & 5 & 140 \\
\hline Vadja & - & 38 & 15 & - & 21 & 7 & 6 & 92 \\
\hline Pärnu & 23 & 18 & 22 & 4 & 17 & 3 & 3 & 111 \\
\hline Rēzekne & 23 & 20 & 50 & 6 & 4 & 2 & 8 & 101 \\
\hline Kemeri & 23 & 9 & - & 11 & 11 & 4 & 0 & 83 \\
\hline $\begin{array}{l}\text { Tilze + } \\
\text { Stoniškiai }\end{array}$ & 31 & 16 & 6 & 5 & 5 & 2 & 5 & 80 \\
\hline $\begin{array}{l}\text { Number of exa- } \\
\text { mined samples }\end{array}$ & 262 & 123 & 20 & 57 & 42 & 63 & 217 & $\begin{array}{c}\text { Total } \\
784\end{array}$ \\
\hline
\end{tabular}

- not determined 
boreholes, located in the NW area of the East European Platform (Fig. 1). From each sample, $40-150$ grains, $0.1-0.05 \mathrm{~mm}$ in size, were examined by the immersion method under the polarizing microscope.

\section{DISTRIBUTION OF OVERGROWTHS IN THE SEQUENCE}

Authigenic overgrowths are rather common in detrital grains of feldspars in the Devonian rocks of the East Baltic. They are found on grains of orthoclase, plagioclase, and microcline. In the examined Devonian rocks, orthoclase was clearly dominating among feldspars, constituting always more than $90 \%$ of feldspar (Kleesment, 1995; Kleesment \& Mark-Kurik, 1997a, 1997b). For this reason, the following discussion concerns first of all potassium feldspar.

The frequency of authigenic rims of feldspars was clearly variable in different rocks. They occurred most abundantly in loose sandstones (Table 2), in which commonly $30-50 \%$ (Figs. 2, 3), sometimes up to $90 \%$ of feldspar grains were surrounded by authigenic overgrowths. The overgrowths were absent or rare (5-20\%) in loose sandstones in which kaolinite is a substantial component of clay cement, for example, on some levels of the K̦emeri and Stoniškiai regional stages.

In dolomite-cemented sandstones feldspar grains with authigenic overgrowths were usually less numerous and more varied than in loose ones, but in some cases both sandstones were quite comparable.

Gypsum-cemented sandstone occurred rarely in the explored sections. Only 20 samples of this kind were examined. The amount of rimmed feldspar grains in gypsum-cemented sandstone was extremely variable: in sandstones of Pärnu age their content was close to that of loose sandstones, but in gypsum-cemented sandstones of Rēzekne age feldspar grains with overgrowths were relatively more abundant than in loose sandstones (Table 2). In the last case sandstones intercalated with dolomite.

In siltstones rimmed feldspar grains were slightly less abundant than in sandstones. Characteristically, in siltstones feldspar overgrowths occurred more frequently in dolomite-cemented varieties (Table 2). This can be explained by a coarser texture of these rocks in comparison with clay-cemented ones.

The rimmed feldspar grains were clearly less abundant in clays, dolomites, and domerites than in sand- and siltstones (Table 2; Figs. 2, 3). In the former rocks the overgrowths were often completely absent, only sandy-silty varieties contained more than $10 \mathrm{vol} \%$ of such grains.

The amount of rimmed feldspar grains in sand- and siltstones depends notably on the location of these rocks in the sequence. Relatively large numbers of overgrowths were recorded in sandy deposits with frequent dolomitic and clayey interlayers, as in the upper part of the Narva Regional Stage, in the Kernave Regional Substage, and in the Aruküla Regional Stage (Table 2; Figs. 2, 3). The 


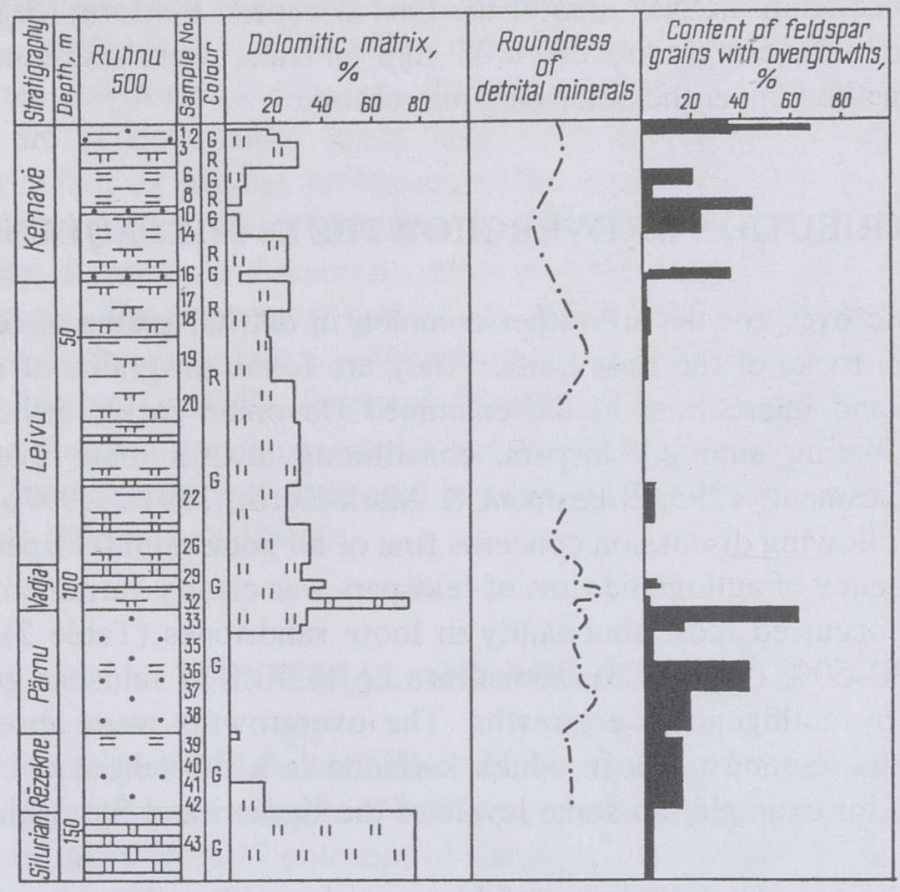

\begin{tabular}{|c|c|c|c|}
\hline$\therefore \cdot$ & Sandstone & & $\begin{array}{l}\text { Feldspar grain } \\
\text { with overgrowth }\end{array}$ \\
\hline$=\ldots$ & Siltstone & - & Roundness \\
\hline -- & Clay & A & $\begin{array}{l}\text { Presence of } \\
\text { authigenic anatase }\end{array}$ \\
\hline$\pi \pi$ & Domerite & $R$ & $\begin{array}{l}\text { Dominating colour } \\
\text { Red }\end{array}$ \\
\hline $\begin{array}{|ll|}11 & 11 \\
\end{array}$ & $\begin{array}{l}\text { Dolamitic } \\
\text { matrix }\end{array}$ & G & $\begin{array}{l}\text { Dominating colour } \\
\text { Grey }\end{array}$ \\
\hline
\end{tabular}

Fig. 2. Distribution of feldspar grains with authigenic overgrowths in the Ruhnu-500 core.

amount of rimmed feldspar grains was greatest in red-coloured complexes, especially when sandstones contained frequent interlayers of reddish-brown clay and/or multicoloured mottled domerite (Fig. 2, samples 2, 10, 16; Fig. 3, samples $2,8,10)$. Rimmed feldspar grains were less abundant in sandstones which occurred as interlayers in grey clay and dolomitic rocks (Fig. 3, samples 20, 22, $24,25)$, and in large sandy complexes without interlayers of clay and dolomitic rocks. This could be well observed in the Rēzekne, Pärnu, and Burtnieki regional stages (Table 2; Figs. 2, 3), except in few cases that these sandstones contained dolomitic or clayey interlayers (Fig. 2, samples 33, 36; Fig. 3, samples 2, 36). 


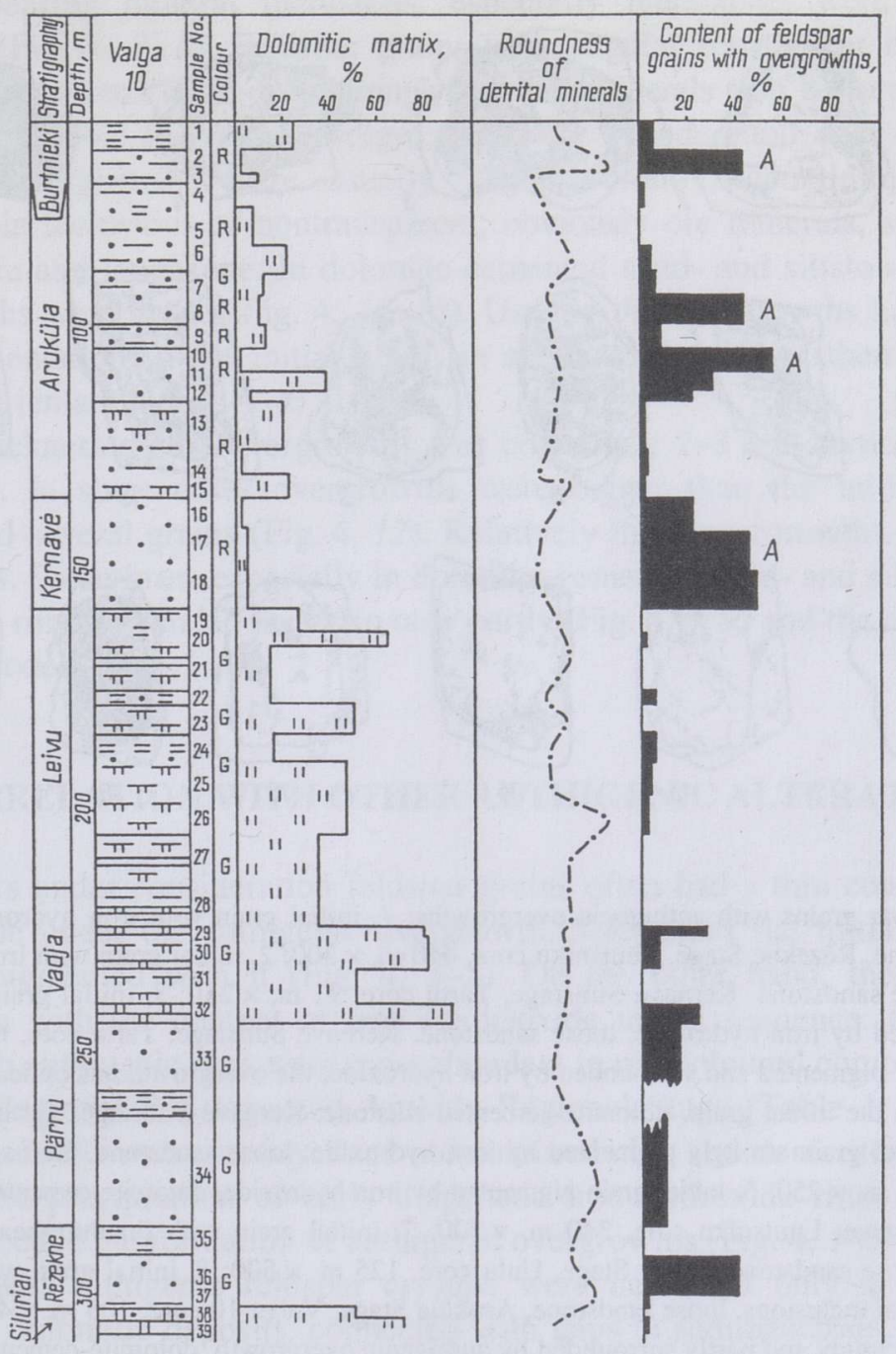

Fig. 3. Distribution of feldspar grains with authigenic overgrowths in the Valga-10 core. For legend see Fig. 2.

\section{DESCRIPTION OF OVERGROWTHS}

In the examined deposits the authigenic overgrowths were mostly transparent and angular, surrounding rounded, often cloudy feldspar grains (Fig. 4, 1-8). However, sometimes the initial grain was nearly clear or clear (Fig. 4, 9-15). On the surface of the enclosed detrital grains often iron oxide coatings were present (Fig. 4, 1-4). Sometimes the initial grain was opaque, strongly pigmented by iron hydroxides (Fig. 4, 5). Inside the grains, along the cleavage planes, authigenic 

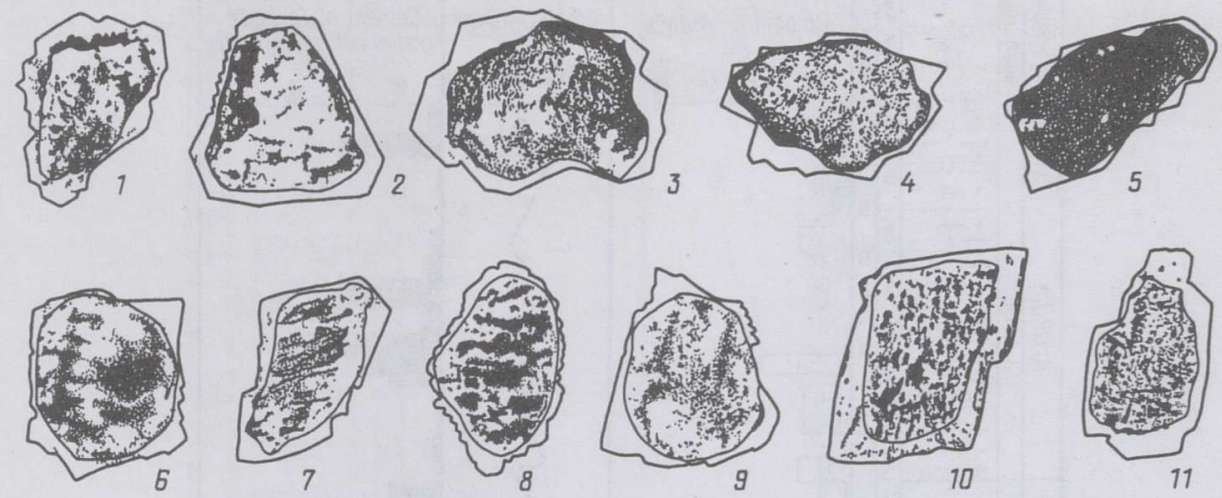

10

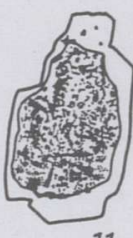

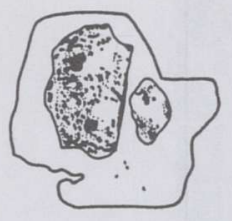

12

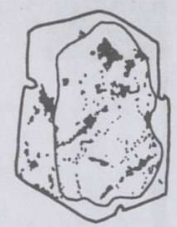

13

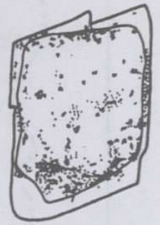

14

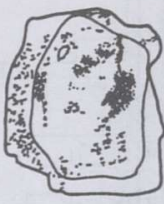

75

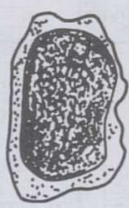

16

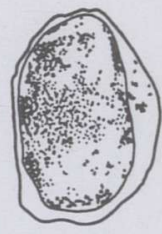

17

Fig. 4. Feldspar grains with authigenic overgrowths: 1 , initial grain with iron hydroxide coating, loose sandstone, Rēzekne Stage, Luutsniku core, $440 \mathrm{~m}, \times 300 ; 2$, initial grain with iron hydroxide coating, loose sandstone, Kernavẻ Substage, Tartu core, $91 \mathrm{~m}, \times 250$; 3, initial grain pigmented and surrounded by iron hydroxide, loose sandstone, Kernavé Substage, Tartu core, $61 \mathrm{~m}, \times 600$; 4 , initial grain pigmented and surrounded by iron hydroxide, the overgrowth has optical orientation different from the initial grain, dolomite-cemented siltstone, Kernavè Substage, Tartu core, $50 \mathrm{~m}$, $\times 450$; 5 , initial grain strongly pigmented by iron hydroxide, loose sandstone, Kernavè Substage, Tartu core, $64 \mathrm{~m}, \times 250$; 6 , initial grain pigmented by iron hydroxide, dolomite-cemented sandstone, Kernavè Substage, Luutsniku core, $340 \mathrm{~m}, \times 300 ; 7$, initial grain with titanium-bearing mineral inclusions, loose sandstone, Pärnu Stage, Uulu core, $125 \mathrm{~m}, \times 500 ; 8$, initial grain with titaniumbearing mineral inclusions, loose sandstone, Aruküla Stage, Valga-10 core, $105 \mathrm{~m}, \times 450$; 9 , initial grain slightly cloudy and partly surrounded by authigenic overgrowth, dolomite-cemented siltstone, Kernavè Substage, Tartu core, $50 \mathrm{~m}, \times 600 ; 10$, initial grain slightly cloudy, along the cleavage inclusions of ilmenite and leucoxene, Burtnieki Stage, Tõrva outcrop, $\times 450 ; 11$, initial grain slightly cloudy, with inclusions of ilmenite and leucoxene, Burtnieki Stage, Tõrva outcrop, $\times 300$; 12, corroded authigenic rim, surrounding two slightly corroded grains, dolomite-cemented sandstone, Kernavė Substage, Tartu core, $95 \mathrm{~m}, \times 500 ; 13$, clear initial grain with corroded overgrowth, dolomite-cemented siltstone, Pärnu Stage, Riešutine core, $300 \mathrm{~m}, \times 300 ; 14$, clear initial grain, loose sandstone, Rēzekne Stage, Luutsniku core, $440 \mathrm{~m}, \times 450$; 15, nearly clear initial grain with slightly cloudy and rounded overgrowth, gypsum-cemented sandstone, Pärnu Stage, Riešutine core, $300 \mathrm{~m}, \times 450 ; 16$, initial grain strongly pigmented by iron hydroxide, with slightly cloudy and rounded authigenic overgrowth, dolomite-cemented sandstone, Kernavė Substage, Tartu core, $95 \mathrm{~m}, \times 450 ; 17$, slightly cloudy initial grain surrounded by nearly clear authigenic overgrowth,

loose sandstone, Kernavẻ Substage, Gorodenka outcrop, $\times 450$. 
titanium-bearing mineral inclusions, especially leucoxene, were frequently observed (Fig. 4, 7, 8). Feldspar grains with angular transparent overgrowths were described from levels with strongly rounded minerals (Fig. 3, samples 2, 26), however, in some cases the overgrowths were rounded too (Fig. 4, 15-17). Rounded overgrowths were usually slightly cloudy, containing scattered microscopic inclusions of nontransparent, obviously ore minerals, such as iron (hydr)oxide and leucoxene. In dolomite-cemented sand- and siltstones corroded overgrowths were found (Fig. 4, 12, 13). Usually the overgrowths had a similar optical orientation to the initial grain; in some levels part of them were of a different orientation (Fig. 4, 4).

The thickness of the overgrowths was commonly $2-3 \mu \mathrm{m}$, sometimes up to $20-30 \mu \mathrm{m}$. In some cases overgrowths were bigger than the initial grain or surrounded several grains (Fig. 4, 12). Relatively thick overgrowths occurred in sandstones. Sometimes, especially in dolomite-cemented sand- and siltstones, the authigenic rim surrounded the grain only partly (Fig. 4, 4,9) and the rim could be partly corroded.

\section{CORRELATION WITH OTHER AUTHIGENIC ALTERATIONS}

In rocks under consideration feldspar grains often had a thin coating of iron (hydr)oxide under the authigenic overgrowth. Sometimes the initial grain was strongly pigmented with it (Fig. 4, 3-5). On the other hand, there is direct correlation with the content of iron (hydr)oxide in the sequence: the feldspar grains with authigenic rims were most abundant in red-coloured complexes of the Kernave Regional Substage and Aruküla Regional Stage (Table 1; Figs. 2, 3), also in the levels with interlayers of red-coloured clay and domerite (Figs. 2, 3). Clearly, the precipitation of early diagenetic iron hydroxide rims on feldspar grains preceded the formation of authigenic overgrowths (Fig. 4, 1-5).

Individual authigenic feldspar crystals were described only in two cases, both from dolomitic deposits, connected with gaps in sedimentation. Authigenic overgrowths were absent in these rocks.

In the examined sequence there exists clear relationship between the abundance of authigenic feldspar overgrowths and authigenic titanium-bearing minerals in rocks. As mentioned above, the feldspar grains, surrounded by authigenic rims, contained authigenic titanium-bearing mineral inclusions (Fig. 4, $7,8)$. Characteristically, in rocks where leucoxene grains were surrounded by transparent crystals of authigenic anatase, most of the feldspar grains had clear, transparent authigenic rims (Fig. 3, samples 2, 8, 10, 17). Obviously, titaniumbearing minerals and authigenic feldspar overgrowths were formed in similar conditions and time, but the formation of leucoxene started earlier (Fig. 5). It can be mentioned that commonly leucoxene-rich levels contain abundantly feldspar grains with authigenic rims. 


\begin{tabular}{|c|c|c|c|c|c|}
\hline \multirow{2}{*}{ Process } & \multirow{2}{*}{ Burial } & \multicolumn{4}{|c|}{ Diagenesis } \\
\hline & & Early & Middle & Late & Regressive \\
\hline Compaction & -- & -- & & & \\
\hline $\begin{array}{l}\text { Formation of } \\
\text { leucoxene }\end{array}$ & & --- & & & \\
\hline $\begin{array}{l}\text { Formation of } \\
\text { iron oxide coatings }\end{array}$ & & & & & \\
\hline $\begin{array}{l}\text { Formation of } \\
\text { authigenic feldspar }\end{array}$ & & & & & \\
\hline $\begin{array}{l}\text { Formation of } \\
\text { feldspar overgrowths }\end{array}$ & & & - & & \\
\hline $\begin{array}{l}\text { Formation of } \\
\text { dolomitic cement }\end{array}$ & & - & & - & \\
\hline $\begin{array}{l}\text { Formation of } \\
\text { authigenic anatase }\end{array}$ & & & 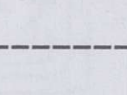 & & \\
\hline $\begin{array}{l}\text { Formation of } \\
\text { authigenic apatite }\end{array}$ & & & & -- & \\
\hline
\end{tabular}

Fig. 5. Paragenesis of some diagenetic formations in the investigated sequence.

The correlation between chloritization and frequency of authigenic feldspar overgrowths is somewhat unclear. Loose sandstones, rich in chlorite, abounded in rimmed feldspar grains, however, chlorite-rich varieties of dolomite-cemented sandstones sometimes contained few feldspar grains with overgrowths.

Often in levels with abundant rimmed feldspars, authigenic apatite was present in the layers containing numerous fragments of phosphorus-bearing fauna. The fragments were rounded throughout the redepositional process, and in diagenesis they served as crystallization centres for authigenic crystals.

\section{CONCLUSIONS}

Based on the character of the rims, regularities of the distribution, and inferred paragenesis of diagenetic alterations in the examined sections, the time and conditions for the formation of the authigenic feldspar overgrowths can be determined.

The overgrowths were absent or occurred rarely as small rims on feldspar grains in clays, dolomites, and domerites. This indicates that there were no 
conditions for the formation of overgrowths during the early phase of diagenesis. Compaction of the rocks inhibited further alteration of grains.

The occurrence of feldspar overgrowths on the iron (hydr)oxide film indicates that they formed after iron oxidation and migration of iron-rich solutions during early diagenesis (Fig. 5).

The content of feldspar overgrowths in dolomite-cemented sand- and siltstones is highly variable. In some rocks overgrowths are rare, in others abundant, being indicative of two generations of dolomitic cement. The growth of authigenic rims on feldspar grains started before the first phase of the formation of dolomitic cement in sand- and siltstones; it took place during cementation and, especially intensively, after the first phase of cementation of these rocks. During the second phase of the dolomitic cementation in late diagenesis the conditions for the formation of authigenic feldspar overgrowths were absent. There occurred some corrosion of overgrowths.

The authigenic feldspar overgrowths in the examined rocks have mainly formed during the middle phase of diagenesis (Fig. 5). The fact that the overgrowths were most abundant and relatively thick in loose sandstones indicates that high permeability is an important factor in this process. Additionally, close association of authigenic feldspar overgrowths with levels containing dolomitic and clayey interlayers, especially red ones, permits us to conclude that the conditions for forming the authigenic feldspar rims were particularly good in closed sandy bodies where saturated solutions circulated. A low share of authigenic feldspar in rocks suggests that feldspar may have been furnished by dissolution-precipitation processes within the layer. The intake of some potassium from the outside was not necessary. A favourable factor for the formation of feldspar overgrowths was the presence of abundant iron and, probably, phosphorus in the solution. A restraining factor was the occurrence of kaolinite. The absence of feldspar overgrowths by the presence of kaolinite, which formed in acidic conditions, shows that the overgrowths precipitated in an alkaline environment.

The feldspar overgrowths have apparently formed at the same time and in the similar conditions as the authigenic anatase (Fig. 3, samples 2, 8, 10, 17). The examined material showed no evidence of the connection with the burial depth. Also, no corrosion of authigenic overgrowths in outcrops was established; however, this process has been described by several researchers (Goldich, 1938; Chernyakhovskij, 1991).

\section{ACKNOWLEDGEMENTS}

I would like to thank Enn Pirrus for critical remarks and Kaie Ronk for drawings. The research was supported by grant No. 2723 of the Estonian Science Foundation. 


\section{REFERENCES}

Baskin, Y. 1956. A study of authigenic feldspars. J. Geol., 64, 2, 132-155.

Chernyakhovskij, A. G. 1991. Sovremennye kory vyvetrivaniya. Nauka, Moscow (in Russian).

Dapples, E. C. 1979. Diagenesis of sandstones. In Diagenesis in Sediments and Sedimentary Rocks (Larsen, G. \& Chilinger, G. V., eds.). Elsevier, Amsterdam, 31-98.

Diehl, S. F. \& Goldhaber, M. B. 1995. Feldspar diagenesis in Cambrian clastic rocks of the Southern Ozarn Mountains and Reelfoot Rift, southeastern Missouri and northeastern Arkansas. Implications for Missisippi Valley type ore genesis. U.S. Geol. Survey Bull., 1989-F, 1-18.

Faure, G. 1992. Isotopic records in detrital and authigenic feldspars in sedimentary rocks. In Isotopic Signatures and Sedimentary Records (Clauer, N. \& Chaudhuri, S., eds.). Springer-Verlag, Berlin, 215-238.

Goldich, S. S. 1938. A study in rock weathering. J. Geol., 46, 1, 17-58.

Hansley, P. L. 1995. Diagenetic and burial history of the Lower Permian White Rim sandstone in the Tar Sand Triangle, Paradox Basin, southeastern Utah. U.S. Geol. Survey Bull., 2000-I.

Khodak, J. A. 1956. Vtorichnye mineraly nizhnekembrijskikh otlozhenij Aldanskogo rajona Yakutskoj ASSR. In Voprosy mineralogii osadochnykh obrazovanij (Lazarenko, E. K., ed.). Vols. 3-4. Lvov, 468-485 (in Russian).

Kleesment, A. 1995. Litoloogilis-mineraloogiliste kriteeriumite osa Liivimaa devoni liigestamisel. In Liivimaa geoloogia (Meidla, T., Jõeleht, A., Kalm, V. \& Kirs, J., eds.). Tartu, 72-77.

Kleesment, A. 1997. Devonian sedimentation basins. In Geology and Mineral Resources of Estonia (Raukas, A. \& Teedumäe, A., eds.). Estonian Academy Publishers, Tallinn, 205-208.

Kleesment, A. \& Mark-Kurik, E. 1997a. Lower Devonian. In Geology and Mineral Resources of Estonia (Raukas, A. \& Teedumäe, A., eds.). Estonian Academy Publishers, Tallinn, $107-112$.

Kleesment, A. \& Mark-Kurik, E. 1997b. Middle Devonian. In Geology and Mineral Resources of Estonia (Raukas, A. \& Teedumäe, A., eds.). Estonian Academy Publishers, Tallinn, $112-121$.

Kopeliovich, A. V. 1965. Epigenez drevnikh tolshch yugo-zapada Russkoj platformy. Nauka, Moscow (in Russian).

Kossovskaya, A. G. \& Shutov, V. D. 1956. Zonal'nost' izmeneniya terrigennykh porod pri epigeneze i nachal'nom metamorfizme v usloviyakh geosinklinal'noj zony. In Voprosy mineralogii osadochnykh obrazovanij (Lazarenko, E. K., ed.). Vols. 3-4. Lvov, 452-467 (in Russian).

Pettijohn, F. 1957. Sedimentary Rocks. Harper Geoscience Series, New York.

Pollastro, R. M. 1989. Mineralogic and textural relations in deeply buried rocks of the Simpson group (Middle Ordovician) - implications in diagenesis and petroleum geology. Oklahoma Geol. Survey Circular, 90, 194-208.

Pustovalov, L. V. 1956. O vtorichnykh polevykh shpatakh v osadochnykh porodakh. In $O$ vtorichnykh izmeneniyakh osadochnykh porod. Trudy GIN, 5, 207-222 (in Russian).

Rajulu, G. B. V. \& Nagaraja, H. R. 1967. Authigenic feldspars from the Lower Kaladgi arkoses of Jamkhandi, Mysore State, India. J. Sed. Petrol., 37, 2, 707-709.

Rukhin, L. B. 1956. O nekotorykh zakonomernostyakh epigeneza. In Voprosy mineralogii osadochnykh obrazovanij (Lazarenko, E. K., ed.). Vols. 3-4. Lvov, 425-451 (in Russian).

Strakhov, N. M. 1957. Stadii obrazovaniya osadochnykh porod i zadachi ikh izucheniya. In Metody izucheniya osadochnykh porod, I (Strakhov, N. M., ed.). Gosgeoltehizdat, Moscow, 7-28 (in Russian).

Viczian, I. 1992. Diagenetic neoformations of Middle Triassic evaporitic and carbonate rocks, Mecsek mts (S. Hungary). Acta Miner.-Petr., Szeged, XXXIII, 13-24.

Viswanathiah, M. \& Rao, S. 1968. Occurrence of authigenic feldspars in arcosic sandstones of Kaladgi formations, Badami, Mysore State, India. J. Sed. Petrol., 38, 4, $1344-1347$. 


\title{
PÄEVAKIVI AUTIGEENSETE ÄÄRISTE ESINEMINE BALTIKUMI DEVONI SETETES
}

\section{Anne KLEESMENT}

Päevakivi autigeensete ääriste esinemist on käsitletud Baltikumi devoni 39 puuraugu ja 27 paljandi läbilõike põhjal. Kokku on immersioonmeetodil uuritud 784 proovi. Proovid on võetud kivimitüüpidest, mille hulgas on pudedad, dolomiitse ja kipstsemendiga liivakivid, aleuroliidid, domeriidid, dolomiidid ja savid. Kivimid lasusid maapinnast kuni 1000 m sügavusel.

Päevakivi autigeensed äärised on valdavalt läbipaistvad, puhtad ja nurgelised. Nende esinemissagedus on maksimaalne pudedates liivakivides. Savides ja domeriitides on äärised harvad, neid leidub peamiselt liivakat lisandit sisaldavates erimites. Seose alusel teiste diageneetiliste muutustega võib eeldada ääriste teket diageneesi keskmistes staadiumides. Eriti ulatuslik on ääriste formeerumine olnud punase savi ja/või domeriidi vahekihte sisaldavates pudedates liivakivides. Protsessile on kaasa aidanud üleküllastatud lahuste tsirkulatsioon suletud, heade filtratsiooniomadustega kollektorites. Rauarikaste kihtide olemasolu on soodustanud, kaoliniidi moodustumine aga tõkestanud ääriste teket. Lasumise sügavus ei ole mõjustanud ääriste moodustumist.

\section{АУТИГЕННЫЕ КАЕМКИ ОБРАСТАНИЯ НА ЗЕРНАХ ПОЛЕВОГО ШПАТА В ОТЛОЖЕНИЯХ ДЕВОНА ПРИБАЛТИКИ}

\author{
Анне КЛЕЕСMEHT
}

В целях изучения аутигенных каемок на зернах полевого шпата проанализированы 784 образца пород из 39 разрезов буровых скважин и 27 разрезов обнажений с использованием иммерсионного метода. Породы представляли собой рыхлые и сцементированные песчаники и алевролиты, домериты, доломиты и глины. Рассмотрены уровни до глубины 1000 м от дневной поверхности.

Аутигенные каемки на зернах полевого шпата в большинстве случаев чистые, прозрачные и неокатанные. В максимальном количестве они встречаются в рыхлых песчаниках. В глинах и домеритах каемки редки и чаще представлены в обогащенных обломочным материалом разновидностях. Образование этих каемок происходило в средних стадиях диагенеза, причем особенно интенсивно в рыхлых песчаниках, переслаивающихся с красноцветными домеритами и/или глинами. Присутствие железа способствовало, а каолинизация препятствовала регенерации зерен полевых шпатов. Характер процесса образования каемок не имеет связи с глубиной залегания пород. 